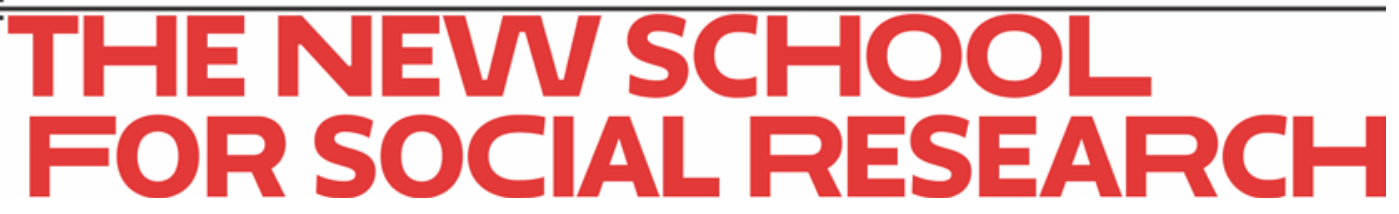

Francisco A. Martínez-Hernández

\title{
The Political Economy of Real Exchange Rate Behavior: Theory and Empirical Evidence for Developed and Developing Countries, 1960- 2010
}

April 2017

Working Paper 16/2017

Department of Economics

The New School for Social Research 


\title{
The Political Economy of Real Exchange Rate Behavior: Theory and Empirical Evidence for Developed and Developing Countries, 1960-2010
}

Francisco A. Martínez-Hernández*

\begin{abstract}
Empirical results of the PPP hypothesis have constantly shown that relative prices do not converge to the same level, neither in the short nor the long run. Therefore the PPP explanation of the determination of the real exchange rate is not operative to get a reasonable measure of competitiveness at the international level. In this paper, we put forth a different approach based on the works of Ricardo, Marx, Harrod, and Shaikh, which argues that the real relative unit labor cost is the main force that explains the long-run behavior of the real exchange rate. In the second section of the paper we explain the theoretical underpinnings of our proposed approach. In the third section we analyze the role of the real interest rate differential in explaining real exchange rate misalignments. In the fourth section, we present a graphical analysis of the interrelation among the real effective exchange rate, the real unit labor cost ratio, the short-run real interest rate differential, and the trade balance for sixteen OECD countries, Taiwan, and three developing countries for the period 1960-2010. In the fifth section we investigate the long-run relationship between the latter three indexes through cointegrating and error correction models using the ARDLECM framework. The last section provides our conclusions.
\end{abstract}

JEL Classification Numbers: B12, B51, F50, F31, F41, C32

Keywords: Real adjusted unit labor cost, real effective exchange rate, real interest rate differential, trade balance, ARDL-ECM models.

Lecturer Professor of Economics at the State University of New York, NY, U.S. Department of Economics. 


\section{INTRODUCTION}

World trade and international finance have evolved since the time of the classical political economists. Yet mainstream economists have ignored some key lessons of Karl Marx, Roy Harrod and John Maynard Keynes with regard to the understanding of the uneven national and international competitive conditions under capitalism (e.g., the role of differences in technology, wage rate differentials, price rigidities, and the role of money in production). Overall, the consequences of an unequal international trading system have been unbalanced trade and high international levels of indebtedness, which have imposed an expansionary bias for trade surplus countries and a deflationary bias for trade deficit countries (especially for small economies).

This paper adopts a Classical grounded theory of price, which takes into consideration the role of intra-and-inter industrial competition (real competition), productivity, and real wages in the tradable sector. Standard monetary and trade theories insist that unbalanced trade situations are temporary based on the assumption that domestic and external prices will move in such a way as to make countries equally competitive at the international level. Instead, we argue that our alternative theory of price is capable of explaining the level of national and international terms of trade, and thus, the changes in the real exchange rate and the degree of international competitiveness.

Our approach is based on Shaikh $(1980,1991,1999 b)$, and the basic idea is that in the realm of manufacturing production at the national and international scale, due to the fact that capital and intermediate goods are traded in international markets whereas labor remains largely immobile internationally, labor costs are likely to diverge much more across 
countries than other costs of production. Labor costs therefore play a disproportionately important role in competitiveness, in our view. Hence, real unit labor costs in manufacturing (labor cost divided by output per worker) capture a key underlying determinant of competitiveness in traded goods.

The second section develops our alternative approach. We begin with a closed economy and we move on to the open economy. In the third section, drawing mainly on Marx, Harrod and Keynes, we explain why trade imbalances ultimately have an impact on the internal liquidity of the economies and thus on domestic interest rates, and real exchange rates, rather than on relative prices. In the fourth section, we present a graphical analysis of the interrelationship between the indexes of the real effective exchange rate, the real adjusted unit labor cost ratio, the short-run real interest rate differential, and the trade balance for sixteen OECD countries, Taiwan, and three developing countries mostly for the period 1960-2010. The fifth section investigates the nature of the long-run relationship between the three aforementioned indexes and the trade balance through cointegrating and error correction models using the autoregressive distributed lag framework (ARDL-ECM). The last section provides some concluding remarks.

\section{A Classical Framework for the Analysis of Real Exchange Rate}

\section{Theory of Competition, Profit Rate and Industrial Price Formation}

The point of departure for Shaikh's real exchange rate model is the classical theory of competition, which can be traced back to the writings of Smith, Ricardo, and Marx. This Classical approach considers competition as rivalry among firms where producers try to 
obtain a higher share of their market by lowering costs and cutting prices. Thus, firms are seen as constantly trying to reduce costs, mainly through suppression of the growth of real wages and via the introduction, at intervals, of better techniques of production (i.e. increased productivity due to technological changes).

From this Classical point of view, real competition implies that firms within an industry do not necessarily face a similar cost structure (i.e., there are technology differences among firms). In other words, the 'Law of One Price' (LOP) or what Adam Smith and David Ricardo called 'natural price' and Karl Marx 'price of production', forces firms within one industry to sell their products in the market at one price, which eventually, due to the differences in the conditions of production, will bring about different profit margins and profit rates to each firm in a given industry.

Therefore, the operation of the LOP (ignoring transportation cost, taxes, etc.) would create a profit differential among firms within an industry (intra-industrial competition), where the most favorable condition(s) of production (lower cost structure) will get a greater profit rate, because the possession of the best productive technique can allow the most competitive producer to enforce the market-selling price. That is, the price that prevails in one particular market is not the average price of the industry but the least cost-price determined by the most efficient producer(s) in that industry. This price is called the regulating price and the producer is the regulating capital, as distinguished from the average price and the average capital (Ruiz-Nápoles 1996; Shaikh 1999b). In turn, non-regulating capitals will be forced by competition to sell at the same price, and will therefore have a variety of profit rates determined by their own various conditions of production (Shaikh 1999b, 2). 
On the other hand, this 'profit rate heterogeneity' within one industry will not pass unnoticed for long. The profit differential can easily call the attention of other capitalists in other industries, i.e., the other regulating capitals, who are themselves eager for profits. In this regard, the Classical tradition presupposes that the 'free mobility of capital' among different industrial sectors (inter-industry competition) produces the tendency for a rough equalization of profit rates between the previous unequal profit sectors, that is, between the regulating capitals of different industries (Foley 1986; Ge 1993; Guerrero 1995; Antonopoulos 1997; Sarich 2007).

Finally, for the Classical perspective, the dynamic and turbulent process of intra-andinter industrial competition does not require the corresponding equalization of wage rates in order to reach a rough equalization of profit rates across industries (Shaikh 1991, 2). In other words, flows of new capitalist investments into an industry can have a significant impact on supply and prices without necessarily affecting sector wage rates (no full

employment is assumed). Where the mobility of labor is for any reason restricted, wage differentials can persist even though profit rates may be equalized (Botwinick 1988, 250; Shaikh 1991, 2).

\section{Competition and Industrial Relative Prices at National Level}

In this section we start by assuming that at national level intra-industry competition makes regional markets integrated for any given commodity, so that the market prices of either commodity $i$ or $j$ will be roughly the same between regional markets; here, we assume that in general, LOP applies. On the other hand, inter-industry competition will make the above 
common market prices of $P_{i}$ and $P_{j}$ themselves gravitate around their respective regulating prices of production, $P_{i}^{*}$ and $P_{j}^{*}$. Therefore, in the long run we have equations 1 and 2 :

$$
P_{i} \cong P_{i}^{*} \quad ; \quad P_{j} \cong P_{j}^{*} \quad ; \quad \frac{P_{i}}{P_{j}} \cong \frac{P_{i}^{*}}{P_{j}^{*}}
$$

By combining equations 1 and 2 we can get 3 . From 3 follows that in the long run, the ratio of any exchange between commodities $i$ and $j$ (i.e., the domestic terms of trade in the economy) will be approximately equal to the relative regulating prices of those bundles of commodities.

Equation 3 above also shows that within a nation, due to inter-industry competition, the relative prices of production of products $i$ and $j$ are driven by the best-practice producer, i.e., the regulating producer $(\mathrm{Ge} 1993,254)$. The important issue with regard to equation 3 is to understand what the main determinants of the level of these prices are and to understand their implications with regard to the explanation of the long run national terms of trade. To settle these issues, Shaikh $(1984,1998)$ reformulates Pasinetti's presentation (1977) of Sraffa's (1963) price system to show that the relative prices in question can be linked to unit costs, specifically, to total vertically integrated unit labor costs, that is, the quantities of labor directly and indirectly embodied in each physical unit of the commodities system (i.e., what Karl Marx called living and dead labor, or labor values).

On the one hand, Passinetti $(1977,73)$ viewed the system of prices as one where each commodity is produced via the use of a certain physical quantity of labor and a given physical quantity of commodities required as means of production. Accordingly, the value 
added in the economic system is assumed to be divided into two categories: wages and profits. Thus, Passinetti's representation of the price system can be depicted as follows:

$$
p=a_{n} w+p A(1+\pi)
$$

Where $p$ denotes the (row) vector of prices, $w$ (a scalar) the wage rate and $\pi$ (also a scalar) the rate of profit. $A$ denotes a matrix of inter-industry coefficients (or an Input-Output matrix) and $a_{n}$ a row vector of direct labor coefficients.

Based on equation 4, after some algebraic manipulation, Passineti (1977, 76-77) reached his general price system (equation 5), where the profit rate lies at some point between its maximum value ( $\Pi$ ), which corresponds to a theoretical possibility, where the wage rate is zero, and a non-zero profit rate $(\bar{\pi})$ and a positive wage rate $(w)$.

$$
p=\frac{1}{1+\bar{\pi}} a_{n}\left[\frac{1}{1+\bar{\pi}} I-A\right]^{-1} w ; \quad \text { (5) } \quad v=a_{n}(I-A)^{-1} w
$$

With equation 5, Passinetti $(1977,81)$ reinterpreted Leontief's input-output model to show Ricardo's theory of value when in the equation above $\bar{\pi}=0$ (the entire net product, or surplus of the economic system, goes to wages); in this case prices become proportional to the quantities of direct and indirect labor (vertically integrated labor coefficients, $v$ in equation 6 above). However, as soon as $\bar{\pi}>0$, the latter result is no longer so. The quantities of indirect labor $\left((I-A)^{-1}\right)$ come to acquire a greater 'weight' relative to the quantities of direct labor $\left(a_{n}\right)$. Therefore, according to Passinetti, the proportionality between prices and quantities of embodied labor (i.e., the pure labor theory of value) breaks down under conditions of positive profit rates. 
On the other hand, Shaikh (1984) reformulated Passinetti's system of prices using Adam Smith's long run competitive decomposition of price in order to show that relative prices can be linked to relative total vertically integrated unit labor costs. In formal terms, this decomposition of price can be illustrated as follows: let $p, u, \pi$, and $m$ be the per unit price, labor costs, gross profits, and material costs, respectively, of some given commodity. Then by definition we may write $p=u+\pi+m$. However, the materials costs are simply the price of some bundle of materials, which in turn may be decomposed into unit labor costs, profits, and their own material costs one (conceptual) stage back. This decomposition can be repeated on the material costs of the materials bundle itself, and so on, so that without any loss of generality Adam's Smith long run competitive decomposition of price can be represented as (Shaikh 1984, 1998):

$$
\begin{aligned}
p= & u+\pi+m=u+\pi+u^{(1)}+\pi^{(1)}+m^{(1)} \\
& =u+\pi+u^{(1)}+\pi^{(1)}+u^{(2)}+\pi^{(2)}+m^{(2)}+\cdots
\end{aligned}
$$

In equation 7 , the new (residual) material $\operatorname{cost} m^{(1)}$ is smaller than the original material cost $m$. Furthermore, if we repeat the above process we can reduce $m^{(1)}$ to its wages, profits and material costs, so that $m^{(1)}=u^{(2)}+\pi^{(2)}+m^{(2)}$, and then in turn reduce this remaining material cost to its components, and so on, until in the limit there is no residual materials cost at all. In this way, regardless of how the price is actually determined, we can always express it as an infinite series of wages and profits in conceptually receding stages of production (Shaikh 1984, 66).

Along these lines, we can denote the sum of all the direct and indirect (vertically integrated) unit labor costs by $v=u+u^{(1)}+u^{(2)}+u^{(3)}+\cdots$ and that of all the direct and 
indirect (vertically integrated) unit gross profits by $\pi^{T}=\pi+\pi^{(1)}+\pi^{(2)}+\pi^{(3)}+\cdots$. Then equation 7 can be re-expressed as:

$$
p=v+\pi^{T}=v(1+\rho)
$$

Where $\rho=\pi^{T} / v$ the average direct and indirect (i.e. the vertically integrated) profit-wage ratio.

Here we have to bear in mind that this decomposition of price can be applied to any price whatsoever, since it follows from an accounting identity. Hence, it follows that for any two industries $i$ and $j$, respectively, we can always express their relative prices in the form expressed by equation 9, which Shaikh (1984) calls the Fundamental Equation of Prices.

$$
p_{i} / p_{j} \equiv\left(v_{i} / v_{j}\right) *\left(z_{i j}\right)
$$

Where $z_{i j}=\left(1+\rho_{i}\right) /\left(1+\rho_{j}\right)=$ the ratio of the vertically integrated profit-wage ratios.

The Fundamental Equation of Prices shows that the relative prices of any two commodities depends only on two terms: their relative vertically integrated unit labor costs, and their relative vertically integrated gross profit margins. At this point, Shaikh (1984), following Ricardo (1817), intertwines theoretical and empirical results from the analysis of vertically integrated structures to assume that the second term of equation 9 , the ratio of the vertically integrated profit-wage ratios $\left(z_{i j}\right)$, can be viewed as a disturbance term with a stable value around 1. That is, Shaikh assumes that, due to the high interconnectedness among industrial sectors, even large variations between $\rho_{i}$ and $\rho_{j}$ would induce only small variations in relative prices vis-à-vis relative vertically integrated unit labor costs, so that $z_{i j}$ is not structurally relevant in explaining the long-run level of relative prices. 
Hence, equation 10 below can be considered as an excellent approximation to equation 9 .

$$
\frac{P_{i}}{P_{j}} \cong \frac{v_{i}}{v_{j}}
$$

Therefore, equation 10, which reflects Ricardo's theory of value, where the relative amounts of direct and indirect labor used in the production of two goods regulates the exchange value of those goods over time, could be an excellent approximation to measure industrial national terms of trade. In fact, empirical research at the national and international level based on input-output data have shown that the vertically integrated unit labor costs provide an excellent approximation (on the order of $85-90 \%$ ) of relative prices (see Shaikh 1984; Ochoa 1988; Bienenfeld 1988; Milberg and Elmslie 1992; Chilcote 1997; Roman 1997; Ruiz-Nápoles 1996, 2010).

Finally, we have to recall that the development of equation 10 was carried out in real terms. However, due to the fact that even within a single region, the consumer price index (cpi) may differ because not all goods are tradable, then equation 11 takes into account this difference between tradables and nontradables as follows: $\boldsymbol{v}_{r}=\boldsymbol{v} / c p i=$ the real vertically integrated unit labor costs, $p_{T_{i}}=$ the price of some bundle of nationally traded goods and $c p i / p_{T}=$ the adjustment for regional differences in tradable/nontradable prices (Shaikh and Antonopoulos 2013, 209).

$$
\frac{P_{i}}{P_{j}} \cong\left(\frac{\boldsymbol{v}_{r i}}{\boldsymbol{v}_{r j}}\right)\left(\frac{\left(c p i_{i} / p_{T_{i}}\right)}{\left(c p i_{j} / p_{T_{j}}\right)}\right)
$$




\section{Competition, Industrial Relative Prices and International Terms of Trade}

Among economic theories, it is conventionally accepted that competition within a country is regulated by the law of absolute advantage in costs (Guerrero 1995, 20; Félix and Sorokin 2008, 290). However, as has been noted by Harrod (1957, chapter VI) and Shaikh (1980, 1991), when it comes to international trade, neoclassical theory abandons the principle of absolute costs as the main driving force of international competition and replaces it with the principle of comparative costs. That is, for the theory of comparative costs, countries will tend to specialize in the production of those goods that they produce relatively more cheaply. According to this logic, backward nations will tend to specialize in those goods where they have a lower relative cost/price relation, even if they produce those goods inefficiently, or if they produce them more expensively than other advanced nations (Salgado et al. 2010).

Moreover, for comparative advantage theory, regardless of the absolute competitive position of each country, once international trade takes place, trade imbalances, that may initially occur, would eventually tend to disappear via adjustments in domestic and external prices (i.e., adjustment via the real exchange rate). That is, when neoclassical trade models accept Hume's price-specie-flow mechanism (which relies on the quantity theory of money) and J. S. Mill's 'reciprocal national demand' theory, they assume that each country would always be forced to maintain a roughly constant real exchange rate and a balanced trade balance. In other words, the often implicit assumption of neoclassical trade models is that countries with net capital inflows (e.g., due to trade surplus) will have a tendency to see increased domestic prices, while those countries with net capital outflows (e.g., due to trade deficit) will have a tendency to experience a reduction of domestic prices; the net result is 
that this 'automatic mechanism' would tend to leave the real exchange rate constant over time (see Shaikh 1980, 216; Sarich 2006, 473; Martinez 2010, 60; Hunt and Lautzenheiser 2011, 190).

For our alternative real exchange rate model, if free trade is assumed to prevail, absolute advantage would be reflected in international markets by the dominance of regulating prices (from the regulating producer) for each and every tradable commodity. That is, tradable goods are expected to sell for approximately the same international market price, when expressed in a common currency, in every country after accounting for disparities which arise due to differences in transportation costs, indirect taxes and so on (we assume that LOP applies) ${ }^{1}$. Thus, market prices of regulating capitals are expected to conform to the relative, vertically integrated, real unit labor costs of the regulating firms $\left(\boldsymbol{v}_{\boldsymbol{r}}\right)$. So, under these circumstances, international competitiveness, measured by changes in vertically integrated real unit labor costs of the respective tradable sectors, leads to changes in international terms of trade. That is, if the national country's regulating capitals manage to reduce their costs of production and so their prices, then, ceteris paribus, its terms of trade, would decline, depreciating its real exchange rate and increasing its international competitiveness vis-⿳亠丷- $v i$ is its international competitor(s).

In order to bring our alternative framework to the analysis of international competition, equation 11 above would have to be re-arranged in order to get a proper measure of a country's terms of trade, that is, the nominal exchange rate has to be taken into account in

\footnotetext{
${ }^{1}$ It is worth noting that, since by itself, the LOP does not imply a long-run equilibrium real exchange rate (at which balance of trade would be equal to zero), it is possible that the LOP prevails even when there is a trade surplus or trade deficit (see Antonopoulos 1997, 11; Sarich 2007, 472).
} 
order to proper reflect in one common currency changes in international terms of trade. This step can be represented by equation 12 :

$$
\boldsymbol{r x r}_{i j} \equiv \boldsymbol{e}_{i j} * \frac{\boldsymbol{P}}{\boldsymbol{P}^{*}} \approx\left(\frac{\boldsymbol{v}_{\boldsymbol{r}}}{\boldsymbol{v}_{\boldsymbol{r}}^{*}}\right)\left(\frac{\left(c p i / p_{T}\right)}{\left(c p i^{*} / p_{T}^{*}\right)}\right) \quad \text { or } \quad \boldsymbol{r x r}_{\boldsymbol{i j}} \equiv \boldsymbol{e}_{\boldsymbol{i j}} * \frac{\boldsymbol{P}}{\boldsymbol{P}^{*}} \approx\left(\frac{\boldsymbol{v}_{\boldsymbol{r}}}{\boldsymbol{v}_{\boldsymbol{r}}^{*}}\right)\left(\frac{\tau}{\tau^{*}}\right)
$$

In equation 12 , the * represent foreign variables; whereas $\boldsymbol{e}_{\boldsymbol{i} \boldsymbol{j}}$ represents the nominal exchange rate (foreign currency/domestic currency); $\boldsymbol{P}$ and $\boldsymbol{P}^{*}$ represents prices of domestic and foreign tradable goods, respectively; and $\tau$ represents the adjustment for the tradable/nontradable content (i.e. the openness) of the consumption bundle for each country.

Equation 12 clearly shows that the long-term movements of real exchange rates are roughly determined by the productive conditions of each country. That is, the international competitiveness of a country is primarily based on its absolute advantage in terms of product technology, labor productivity and real wages of its tradable sectors (components embedded in $\boldsymbol{v}_{\boldsymbol{r}}$ ). Therefore, differences in these components of the real cost of production (and regulating prices of production) between nations, would tend to determine the changes in their international terms of trade and thus in their long run real exchange rate.

It is worth pointing out that international regulating firms are not located in just one country but they are spread out across different countries in the world. So, here we assume that $v_{r}$ and $v_{r}^{*}$ are the overall best-practice costs of the tradable bundle in question for each country. For this reason, those nations that manage 'to create' or 'to keep up' a large number of regulating capitals in a huge range of industrial tradables could, in general, be capable of getting favorable external conditions like a lower real exchange rate; growing exports (and a higher market share) and thus growing profits relative to other international firms producing 
similar goods; to be able to engage much faster in more research and development; and to be capable of maintaining a sustained trade surplus (e.g., China, Germany, and Japan).

Conversely, those nations that are not able to maintain a sufficient number of regulating capitals in their industrial tradable sectors would, if unprotected from competition, be vulnerable to unfavorable external conditions like a high (uncompetitive) real exchange rate; decreasing exports (and a lower market share) and thus shrinking profits; to be less able to do research and development; and to maintain persistent trade deficits, which would have to be financed by growing external indebtedness.

Having mentioned the key elements of our alternative framework, it is now worth mentioning that in order to undertake an empirical estimation of this theory for a myriad of developed and developing countries, we will use the real unit labor cost $\left(U L C_{r}\right)$ from the manufacturing sector as a proxy for the real vertically integrated unit labor costs and producer price indexes (PPI) as a proxy for tradable prices. The first reason of using direct unit labor cost and producer price indexes is due to their availability for the major OECD countries over a sufficiently long time span. In order to estimate vertically integrated costs, one would need input-output tables for all of the countries involved, over a sufficient time span to permit the creation of an adequate time series. This is beyond the scope of this study. The second reason is that other similar investigations have used direct unit labor cost with good empirical results (see Roman 1997; Martinez 2010; Shaikh and Antonopoulos 2013). The latter reformulation is reflected in equation 13.

$$
r x r_{i j} \equiv e_{i j} * \frac{P_{i}}{P_{j}^{*}} \approx \frac{U L C_{r}}{U L C_{r}^{*}}\left(\frac{\tau}{\tau^{*}}\right)
$$


The conclusions from this framework are the following:

A) The international competitive position of a country, measured by the real unit costs of its tradable, pins its real exchange rate, so the real exchange rate is not free to eliminate trade imbalances.

B) Neither flexible nor quasi-flexible exchange rate regimes will be able to correct structural trade imbalances induced by international competition.

C) Trade surplus and trade deficits are direct consequences of the relative competitive position of a nation. So exchange rate devaluation will only have a temporary effect on national competitiveness if the general conditions of production are not improved.

D) Exchange rate devaluations could be successful only to the extent that they affect the real unit costs (via the real wage) and/or the tradable/nontradables price ratio of consumer goods $(\tau)$, and those changes depend on the ability of workers and consumers to resist such effects (Shaikh 1995; Shaikh and Antonopoulos 2013).

\section{The Role of Interest Rate Differential}

Our fundamental equation 13 developed above, which shows that in the long-run, the real exchange rate is structurally linked (through the intra-and-inter industrial competition processes between international capitalists) to the relative real unit labor costs ratio between two countries, does not necessary presuppose a strict rigid relationship inasmuch as there can be some elements that are not in the equation 13 that could create a short-run deviation between both variables (exchange rate misalignment: $r x r><$ rulcr). However, contrary to the 'automatic' price adjustment mechanism implicit in neoclassical and monetarist trade models which arise due to the inflow and outflow of capital, leaving all trading nations with balanced trade (and a roughly constant real exchange rate over time), the Classical and 
Keynesian traditions use different mechanisms with regard to analyzing capital inflows/outflows, that do not necessarily create a change in internal prices. That is, for the latter traditions, trade imbalances ultimately have an impact on the internal liquidity of the economies and thus on the internal interest rate rather than on relative prices. Therefore, if the level of the national interest rate is high enough to create an attractive interest rate differential (e.g., due to a high trade deficit), eventually, this positive interest rate differential could trigger an important capital inflow into one nation which could create an exchange rate misalignment, and as a consequence, a persistent trade imbalance and external indebtedness.

Drawing on the Classical-Marxian and Keynesian monetary theories of production, this section seeks to show the similarities between these two approaches and their differences with the Quantitative Theory of Money (QTM) and the Post Keynesian determination of the exchange rate. In so doing, we can understand why trade imbalances ultimately have an impact on the internal liquidity of economies and on interest rate differentials but not (at least not automatically) on relative prices as is posited by the PPP hypothesis and the QTM.

\section{Monetary Theory of Production, Interest Rate Differential, and Real Exchange Rate}

Karl Marx was among the first in clarifying the monetary consequences of the exports/imports of gold-money due to trade imbalances for the functioning of the banking and production systems as a whole. In Capital volume III, he shows that changes in goldmoney within an economy (e.g., due to unbalanced trade) lead solely to changes in bank reserves rather than to changes in the price level (Marx 1981, Vol. III, 683). Marx also shows that an increase in bank reserves is generally accompanied by a decline in the rate of 
interest as the banks strive to convert reserves into capital. Conversely, a drop in bank reserves below the legal minimum tends to lead to a rise in the rate of interest. Therefore a decrease in the quantity of gold raises only the interest rate, whereas an increase in the quantity of gold lowers the interest rate; and if not for the fact that the fluctuations in the interest rate enter into the determination of cost-prices, or in the determination of demand and supply, commodity prices would be wholly unaffected by them (Marx 1981, Vol. III, $685)$.

As we could observe in the foregoing paragraph, Marx was also fully aware that changes in the rate of interest will eventually lead to changes in effective demand and will affect the level of production (supply of commodities) via the credit system which itself could help expand/lessen the production and circulation of commodities and money-capital. However, Marx's second criticism of the theory of money refers to the fact that even an ongoing stimulus to effective demand (e.g., due to the extra money in circulation and a lower national interest rate) does not have an increase pari passu on the price level. That is, according to Marx (Marx 1981, Vol. III, 580) 'in periods of predominant credit, the velocity of the money increases faster than commodity-prices, whereas in times of declining credit commodity prices fall slower than the velocity of circulation'. Therefore, under these circumstances, although an increase in effective demand may temporarily increase prices in some sectors, and hence raise profits in some sectors, this increase must eventually lead to an expansion of production to meet the new demand. And as production expands prices will fall until (all other things being equal) they regain their original level (Shaikh, 1980).

According to Milberg (1994, 2002), Keynes argues against the supposed automatic equilibrating forces of relative price adjustments that tend to maintain balanced trade and 
full employment. That is, Keynes rejected the likelihood and efficiency of each of the 'classical' adjustment mechanisms -wages and exchange rates- when persistent unemployment characterizes the economy. In this regard, Milberg (2002) has shown that Keynes' writings from 1929 to 1933 dealt with the issue of free trade, tariffs, and protectionism and the argument that under conditions of less than full employment, a policy of free trade could actually worsen economic conditions.

For instance, in the Macmillan Committee Report of 1930, Keynes wrote the following:

The fundamental ground of the free trade argument is that we ought to take the McKenna Duties off in order that we should stop the making of cars and make something else for which we are better suited. And the logical link between one and the other is through this chain, and no other. Just like the Bank rate argument, it works beautifully in a fluid system. But supposing we get jammed at the point of unemployment, the alternative for a time may be between producing motor cars or producing nothing (CW XX: 114).

In July of 1930, Keynes wrote to Prime Minister J. Ramsay MacDonald the following:

Free trade is profoundly based on the assumption of equilibrium conditions, and in particular that wages always fall to their strict economic level. If they do not, and if for several reasons we do not desire them to, then it is only by means of a tariff that the ideal distribution of resources between different uses, which free trade aims at, can be achieved; and there is an unanswerable theoretical case for a countervailing import duty (and also for an export bounty) equivalent to the difference between the actual wage and the economic wage...

I am no longer a free trader -and I believe that practically no-one else is - in the old sense of the term to the extent of believing in a very high degree of national specialization and in abandoning any industry which is unable for the time being to hold its own. Where wages are immobile, this would be an extraordinarily dangerous doctrine to follow (CW XX: 379-80).

According to Milberg $(2002,240)$, in the Macmillan Committee Report of 1930, one can clearly see Keynes' belief that under conditions of persistent unemployment, the mechanisms which would otherwise transform a situation of differential comparative costs into one of differences in absolute money costs and prices no longer operates. That is, the 
wage adjustment simply does not take place to a sufficient degree to guarantee that the 'law' of comparative advantage will dictate the commodity composition and the balance of trade (Milberg 2002).

Roy Harrod, in his International Economics (Harrod 1957, chapter VI), also argues against the self-equilibrating trade balance assumed by the QTM due to the effects of gold inflows/outflows onto the level of prices. According to Harrod $(1957,113)$, the competitiveness of a country will only be reduced (or increased) if the costs of production are raised (or lowered). Therefore, to Harrod, if the alleged force of the gold inflows/outflows is to be effective in this regard, it must have success in affecting the following factors:

(a) The general level of wages and the general prices of production.

(b) The level of economic activity and employment in the country.

Harrod points out that (a) was the real basis for the 'classical mechanism', in the sense that this theory assumes that an inflow of gold tends to raise prices (and an outflow to reduce them), it being implicitly assumed that factors were fully employed. However, Harrod $(1957,114)$ believed that the flows of gold do not have a direct impact on wages due to the 'notoriously somewhat sticky general level of wages'.

With regard to point (b), Harrod believed that short-term capital movements, triggered by trade imbalances, exchange rate movements, and interest rate differentials, could have an impact on the level of activity and employment. Nonetheless, the potential impact of gold inflows/outflows on domestic prices and the trade balance would hinge on whether or not the factors of production are fully employed. That is, if there is initially considerable 
unemployment and low capacity utilization, an inflow of gold is not expected to have an effect on prices or the general rate of wages. Conversely, if gold inflows lead to a considerable stimulus of economic activity, to the extent that employment and profits also increase substantially, then an increase of the general rate of wages and prices can be expected. According to Harrod $(1957,134)$, only at this point of higher growth of wages and prices, does the 'classical mechanism' come into play.

Finally, for Keynes, like Marx and Harrod, trade imbalances among countries will tend to operate through changes in internal liquidity, from which changes in interest rate differentials, investment and income will be derived, but not changes in relative prices precisely because money-wage flexibility, inter alia, fails to bring about balanced trade. Therefore, persistent trade imbalances - not balanced trade- are the likely outcomes.

$$
r x r_{i j}=f\left(\operatorname{rulcr}_{i j}^{*}, \quad i_{i}-i^{*}\right)
$$

The central hypothesis of this paper, following Shaikh and Antonopoulos (2013) and equation 14 above, is that the structural component of long-run real exchange rates is explained by the relative adjusted real unit labor cost ratio $\left(r u l c r_{i j}^{*}\right)$; meanwhile interest rate differentials $\left(\boldsymbol{i}_{\boldsymbol{i}}-\boldsymbol{i}^{*}\right)$ caused chiefly by trade and payment imbalances may create exchange rate misalignments in the short-to-medium term (around the long-run condition). That is, a positive interest rate differential might induce foreign capital inflows, put the capital account into surplus, raise the nominal exchange rate and hence raise the real exchange rate $\left(e\left(\frac{P}{P^{*}}\right)\right)$-i.e. an appreciation of the real exchange rate. The opposite outcome would be expected if a country with trade surplus maintains a zero or negative interest rate differential. 
At this point, it is worth mentioning that for the Post Keynesian determination of the 'nominal' exchange rate, the interest rate differential is the main factor that determines the changes of the exchange rate in the short-to-medium-to-long term (Harvey 2005, 2013). For the Post Keynesian theory, the breakdown of the Bretton Woods agreements triggered a massive mobility of capitals mainly for speculative purposes rather than to finance international trade transactions, so that the great volatility of the nominal exchange rates of the recent years is mainly explained by capital inflows/outflows pursuing positive profits derived by nominal exchange rate appreciation and positive interest rate differentials.

While our approach agrees with the Post Keynesian explanation of the effect of the interest rate differential (in particular the real ones) on the nominal exchange rate, we believe that such effect pertains to the short-to-medium term. As we argued above, the main determinant of the real exchange rate in the long term is the relative adjusted real unit labor cost ratio. The difference between both theories must be settled by robust empirical analysis.

\section{Statistical Analysis: RXR, RULC, Real Interest Rate Differential, and Trade Balance}

In this section, we include a graphical analysis, and we briefly describe the variables used to compute the indexes of the real effective exchange rate, the adjusted real unit labor cost ratio, and the real interest rate differential for 16 OECD countries for the period 1960-2010. In the appendix, the reader can see the full methodology used for the construction of these three indexes: 


$$
r x r_{c, t}=\frac{p m f g_{i, t} * e_{i, t} * 100}{((p m g * e) o e c d)_{t}}
$$

$r x r$ stands for the index of the real effective exchange rate, $p m f g$ stands for the index of manufacturing prices, $e$ stands for the nominal exchange rate (foreign currency relative to U.S. dollar), (pmfg)oecd stands for a manufacturing price geometric traded weighted average index for 16 OECD countries.

$$
\text { rulcadjratio }_{i, t}=\frac{R U L C a d j_{i, t} * 100}{R U L C a d j O E C D_{t}}
$$

rulcadjratio stands for the index of the adjusted real unit labor cost ratio, RULCadj stands for the adjusted real unit labor cost, and RULCadjOECD denotes the adjusted real unit labor cost geometric traded weighted average index for 16 OECD countries.

$$
\text { realintratedif } f_{t}=\text { intratedif }_{t}-\text { gppiratio }_{t}
$$

realintratediff is the index of the real interest rate differential, intratediff stands for nominal interest rate differential, and gppiratio is a growth rate of a geometric tradedweighted average of the producer price index for 16 OECD countries.

On the left hand side of figure 1, for each of the 16 OECD countries and Taiwan, we plot the real effective exchange rate, the adjusted real unit labor cost ratio, and the trade balance (X/M, goods) for the period 1960 to 2010. For the same period, on the right hand side, we plot the deviation of the real effective exchange rate from the adjusted real unit labor cost ratio (deviation) and the short-run real interest rate differential (measured in percentage). Finally, it is worth mentioning that an increase of real effective exchange rates 
means an appreciation, while a decrease a depreciation, in both cases with regard to its trading partners; the same applies for the adjusted real unit labor cost ratio.

Figure 1: Real Effective Exchange Rate, Adjusted Real Effective ULC Ratio, Trade Balance (X/M), and Real Interest Rate Differential

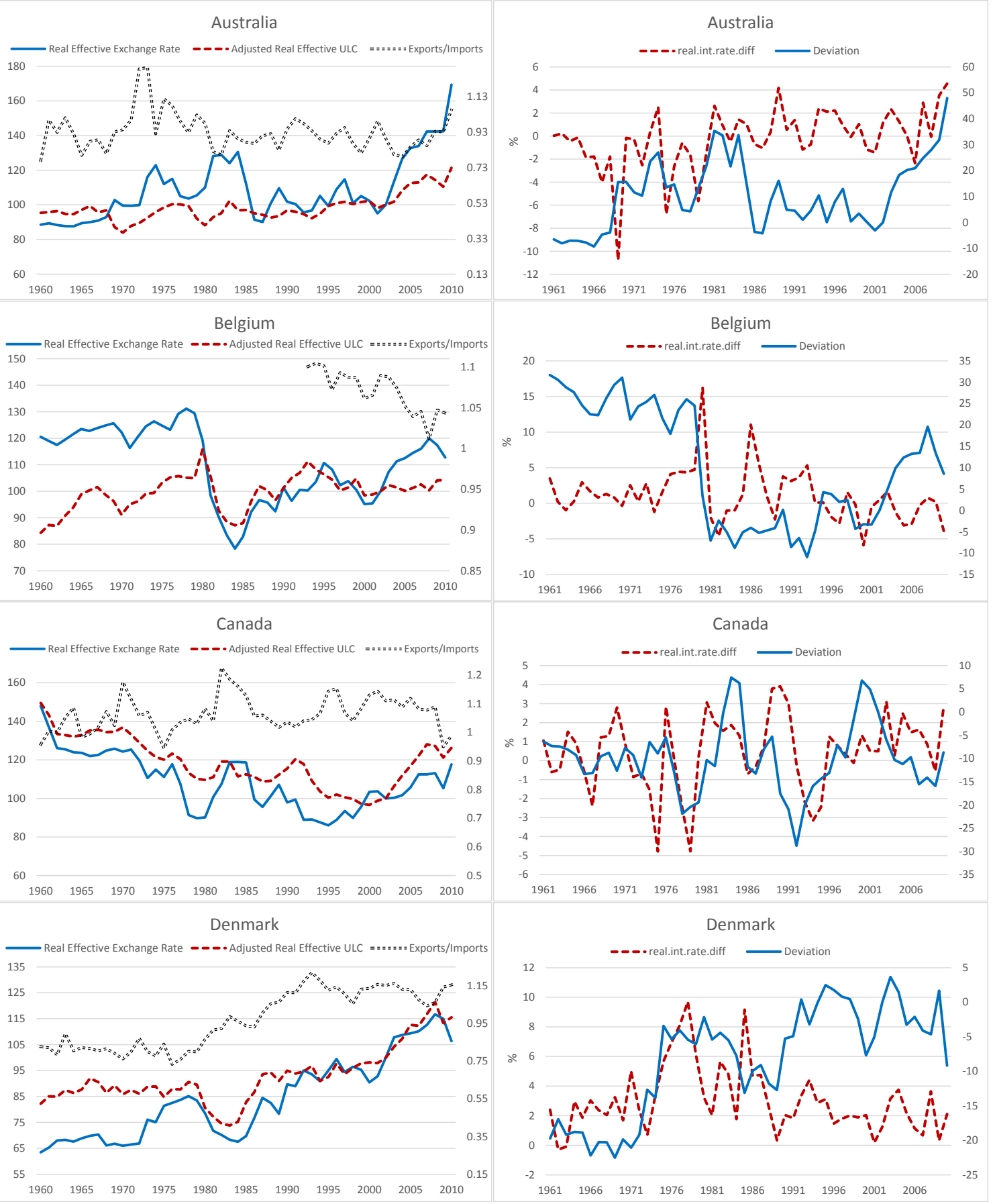




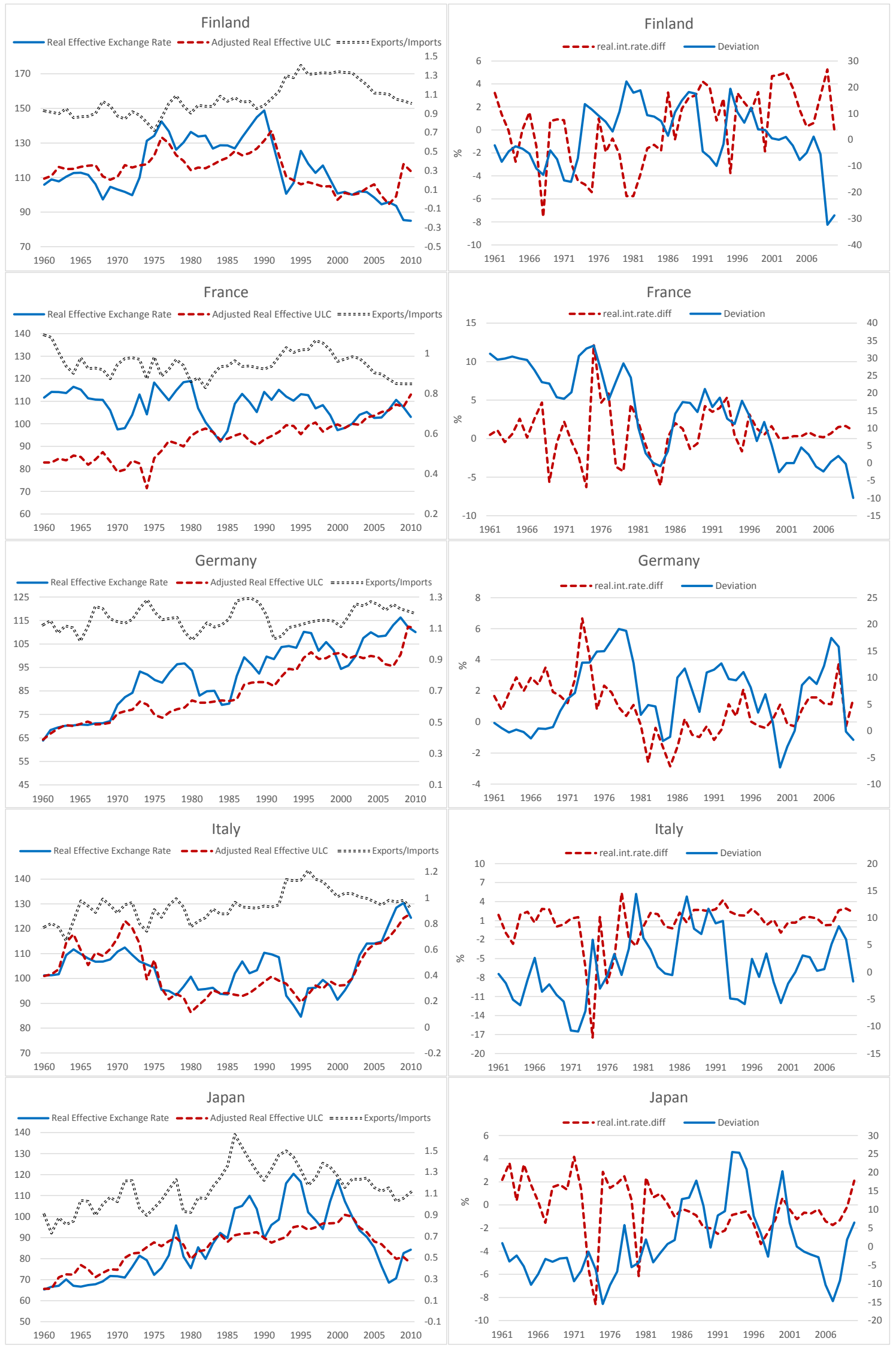




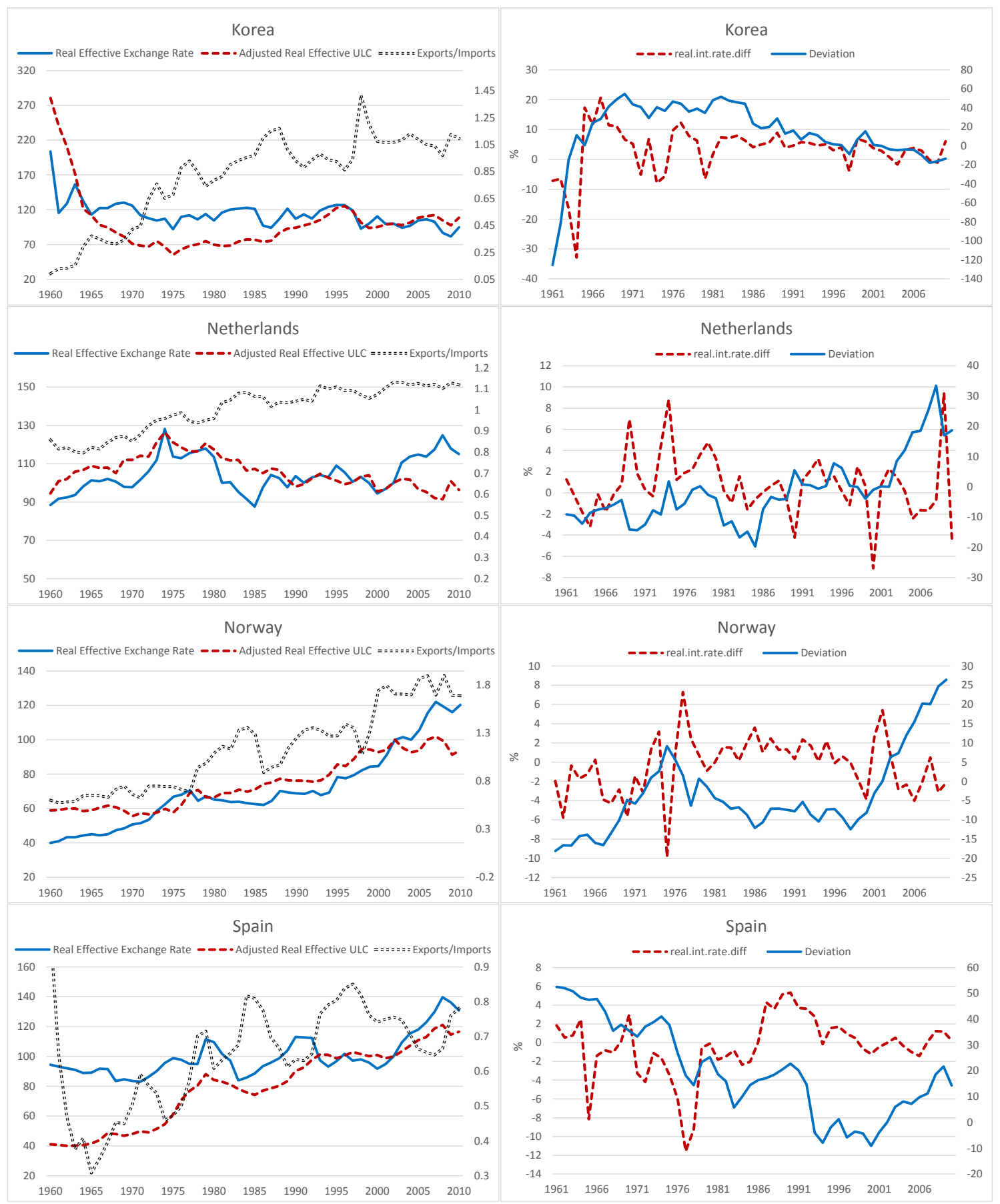




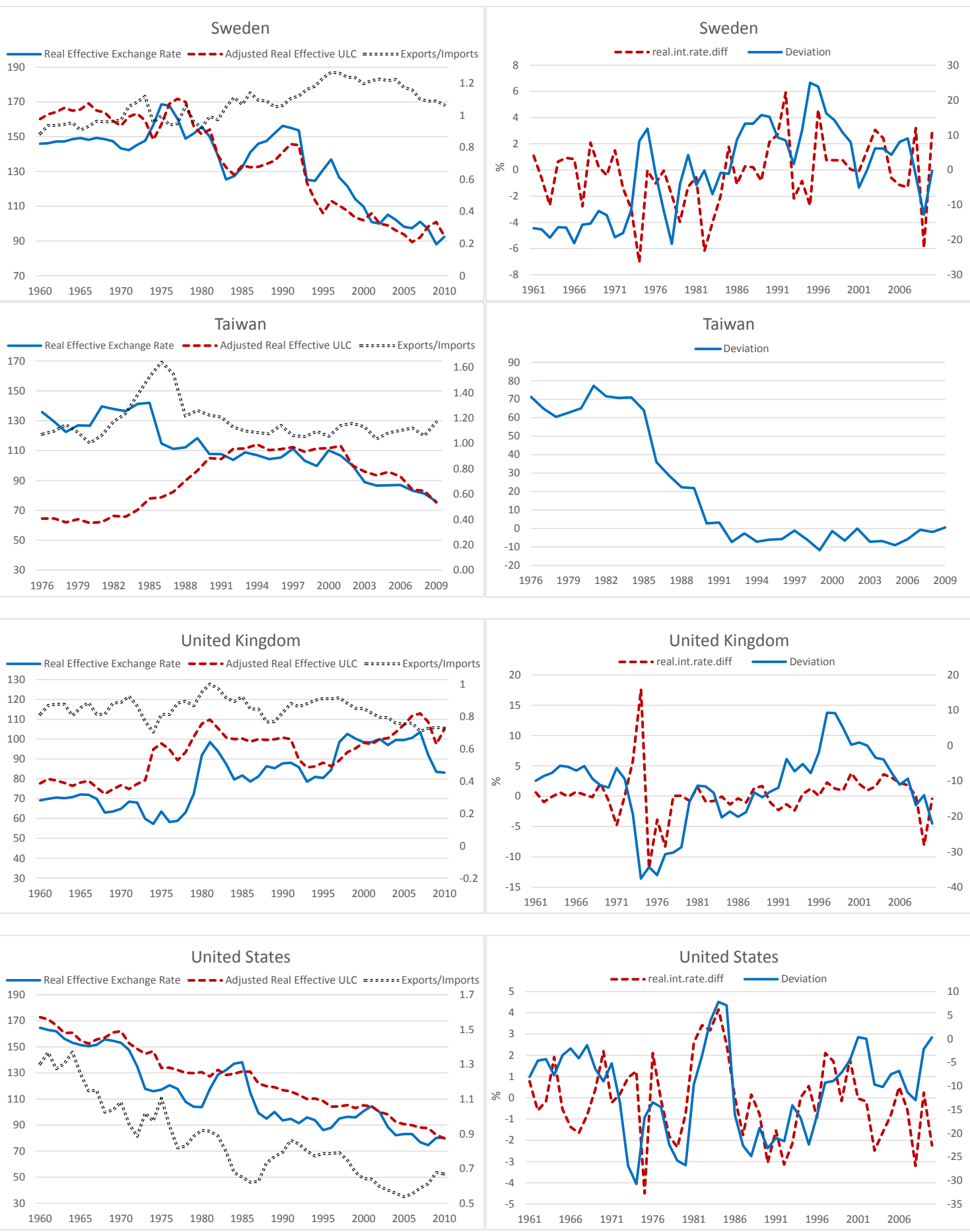

To a large extent, the graphs displayed above seem to corroborate the main hypotheses of this paper. On the one hand, the adjusted real effective ULC ratio seems to determine the level and the long-term trajectory of the real effective exchange rate. That is, for the 16 
OECD countries and Taiwan, both measures move very closely together on their long-run path. Furthermore, we can also see that for all these countries the adjusted real effective ULC ratio and the real effective exchange rate follow a strong opposite short and long-term path with the trade balance, suggesting that the adjusted real effective ULC ratio and the real effective exchange rate capture an important degree of international competitiveness.

On the other hand, on the right hand side graphs, the short run fluctuations or deviations of the real effective exchange rate from its center of gravity (i.e., adjusted $\boldsymbol{U} \boldsymbol{L} \boldsymbol{C}^{*} / \boldsymbol{U} \boldsymbol{L C}$ ) seem to be explained by the real effective interest rate differential; that is, these deviations seem to be caused by positive and negative changes in real interest rate differentials. However, for a few countries, the correlation between the deviations and the real effective interest rate differentials seem not so strong, and for a few years, the latter correlation seems to be negative instead of positive (e.g., Finland and Norway). Nonetheless, by and large, the correlation between the deviations and the real effective interest rate differentials seem to be strong and positive.

On the left hand side of figure 2, for the case of Argentina, El Salvador, and Mexico, we plot the bilateral real exchange rate, the real unit labor cost ratio with respect to the U.S., and the trade balance (X/M, goods) mainly from the period 1960 to 2010. On the right hand side, for different periods according to the availability of data, we plot the deviation of the bilateral real exchange rate from the real unit labor cost ratio (deviation) and the real interest rate differential (measure in percentage). 
Figure 2: Real Exchange Rate, Real ULC Ratio, Trade Balance (X/M), and Real Interest Rate Differential

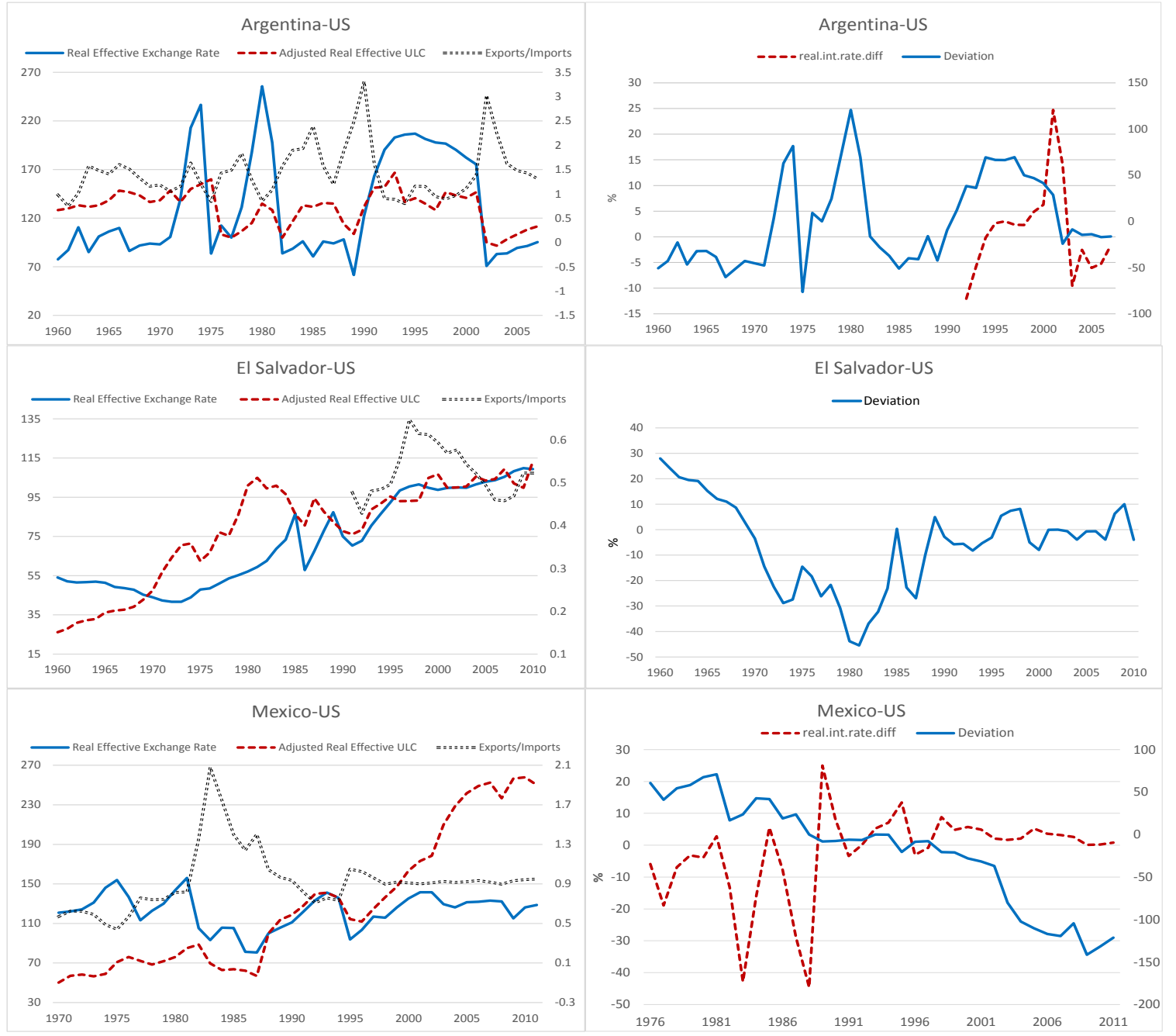

The graphs displayed in figure 2 also seem to corroborate the main hypotheses of this paper. On the one hand, the real ULC ratio seems to determine the level and the long-term trajectory of the bilateral real exchange rate, that is, for the case of Argentina, El Salvador, and Mexico, the latter both measures appear to move very closely each other on their longrun path. Furthermore, we can see that for these three countries the adjusted real effective ULC ratio and the real effective exchange rate follow a strong opposite short and long-term 
path with the trade balance, which means that the adjusted real effective ULC ratio and the real effective exchange rate capture an important degree of international competitiveness.

On the other hand, despite the limited interest rate data for Argentina and Mexico (no data at all for the case of El Salvador), the short run fluctuations or deviations of the bilateral real exchange rate from its center of gravity (i.e. $\boldsymbol{U} \boldsymbol{L} \boldsymbol{C}_{\boldsymbol{r}} / \boldsymbol{U} \boldsymbol{L} \boldsymbol{C}_{r}^{*}$ ) seem to be explained by the real interest rate differential, that is, these deviations seem to be caused by positive and negative changes in real interest rate differentials.

\section{Empirical Evidence of Alternative Real Exchange Rate Determination Based on ARDL-ECM Modeling}

Given that our variables may be potentially I(1), the nature of their long-run trend relationship can be studied via the use of cointegration analysis and error correction models (ECM). The use of the ECM framework has three advantages. First, an ECM incorporates both short-run and long-run (or trend) relationships. Second, the sign and significance of the error correction coefficient (ECC) provide an indication of Granger causality in a nonstationary context (Enders 1995:367). For an error correction model to be stable the ECC has to satisfy the following stability criterion: $-1<\mathrm{ECC} \leq 0$ (Hill et al. 2011, 500). Third, for a stable ECM, the absolute value of the ECC provides an indication of the time that it takes for the variables to reach an approximate equilibrium relationship.

We deployed the autoregressive distributed lag (ARDL) modelling using Microfit 5.0 (Pesaran and Pesaran 2009). The ARDL framework does not require prior unit root testing, thereby eliminating one source of error involved with such tests on relatively small sample sizes. 
Table 1 lists the long-run parameters and the ECC of the seventeen OECD countries (including Taiwan) and three developing countries (Argentina, El Salvador, and Mexico) that showed evidence of being cointegrated, with the log of the adjusted real unit labor cost ratio and the real interest rate differential acting as the long-run forcing variables. The cointegrating results follow from the fact that the F statistic is above the upper bound. The ECC for each country is found to be negative, below one and statistically significant when the first difference of the log of the real effective exchange rate is the dependent variable, suggesting that the log of the adjusted real unit labor cost ratio and the real interest rate differential for any country Granger-causes the log of the real effective exchange rate.

Moreover, the last column of table 1 lists the correlation coefficients of the Trade Balance (TB) and the adjusted real unit labor cost ratio (RULCR). This correlation coefficient turned out to be negative (although with different degrees) for sixteen countries, which suggests that a relative reduction of the real unit labor cost tends to improve the international competitiveness of these nations. However, this correlation coefficient turned out to be positive for Germany, Japan, Norway, and the US, which suggests that a relative reduction of the real unit labor cost tends to worsen the international competitiveness of these nations (more on this below). 
Table 1: Econometric Results

\begin{tabular}{|c|c|c|c|c|c|c|c|c|c|}
\hline & $\begin{array}{c}\text { Intercept } \\
\text { (t-Ratio) } \\
\text { [p-value] }\end{array}$ & $\begin{array}{c}\text { Time Trend } \\
\text { Coefficient } \\
\text { (t-Ratio) } \\
\text { [p-value] }\end{array}$ & $\begin{array}{c}\text { LRULCR } \\
\text { Coefficient } \\
\text { (t-Ratio) } \\
\text { [p-value] }\end{array}$ & \begin{tabular}{|c|} 
Real.Int.Rate.Diff \\
Coefficient \\
(t-Ratio) \\
[p-value]
\end{tabular} & $\begin{array}{c}\text { ECM } \\
\text { Coefficient } \\
\text { (t-Ratio) } \\
\text { [p-value] }\end{array}$ & Dummies & $\begin{array}{l}\text { Regression Date } \\
\text { \& ARDL Order } \\
\text { rulc } \rightarrow \text { rxr or } \mathrm{rxr} \rightarrow \\
\text { rulc }\end{array}$ & $\begin{array}{c}\text { F Statistic } \\
\text { Lower And } \\
\text { Upper Bounds }\end{array}$ & $\begin{array}{l}\text { Correlations } \\
\text { TB \& RULCR }\end{array}$ \\
\hline Argentina & N. A. & N. A. & $\begin{array}{c}1.077 \\
{[120.20]} \\
{[.000]}\end{array}$ & N. A. & $\begin{array}{l}-0.7580 \\
{[-3.22]} \\
{[0.003]}\end{array}$ & N. A. & $\begin{array}{c}\text { 1966-2007 } \\
\operatorname{ARDL}(6,5) \\
\text { Both }\end{array}$ & $\begin{array}{c}5.33 \\
3.31\left[[(0)]^{*}\right. \\
4.32[(1)]^{*}\end{array}$ & $\begin{array}{c}-0.157 \\
1991-2007\end{array}$ \\
\hline Australia & $\begin{array}{c}-5.014 \\
{[-2.761]} \\
{[.010]}\end{array}$ & N. A. & $\begin{array}{c}2.116 \\
{[5.348]} \\
{[.000]}\end{array}$ & $\begin{array}{c}-0.0439 \\
{[-2.515]} \\
{[.017]}\end{array}$ & $\begin{array}{c}-0.518 \\
{[-4.104]} \\
{[.000]}\end{array}$ & N. A. & $\begin{array}{c}1967-2010 \\
\text { ARDL }(2,3,5) \\
\text { rulc } \rightarrow \text { rxr }\end{array}$ & $\begin{array}{c}6.66 \\
4.09[(10)]^{*} \\
5.26[(1)]^{*}\end{array}$ & $\begin{array}{c}-0.191 \\
1960-2010\end{array}$ \\
\hline Belgium & N. A. & $\begin{array}{c}0.011 \\
{[5.481]} \\
{[0.000]}\end{array}$ & $\begin{array}{c}0.911 \\
{[53.727]} \\
{[.000]}\end{array}$ & $\begin{array}{c}.0107 \\
{[1.992]} \\
{[.057]}\end{array}$ & $\begin{array}{c}-0.527 \\
{[-6.393]} \\
{[.000]}\end{array}$ & N. A. & $\begin{array}{c}\text { 1980-2010 } \\
\text { ARDL }(1,0,2) \\
\text { rulc } \rightarrow \text { rxr }\end{array}$ & $\begin{array}{c}17.73 \\
4.25[(10)]^{*} \\
5.41[(1)]^{*}\end{array}$ & $\begin{array}{c}-0.006 \\
1997-2010\end{array}$ \\
\hline Canada & N. A. & N. A. & $\begin{array}{c}1.006 \\
{[77.007]} \\
{[.000]}\end{array}$ & $\begin{array}{c}-0.229 \\
{[-2.248]} \\
{[.042]}\end{array}$ & $\begin{array}{c}-0.302 \\
{[-2.715]} \\
{[.016]}\end{array}$ & N. A. & $\begin{array}{c}1984-2010 \\
\text { ARDL }(2,4,6) \\
\text { Both }\end{array}$ & $\begin{array}{c}10.23 \\
3.10[(10)]^{*} \\
4.31[(1)]^{*}\end{array}$ & $\begin{array}{c}-0.378 \\
1960-2010\end{array}$ \\
\hline Denmark & N. A. & N. A. & $\begin{array}{c}1.01 \\
{[150.044]} \\
{[.000]}\end{array}$ & $\begin{array}{c}-0.026 \\
{[-3.267]} \\
{[.003]}\end{array}$ & $\begin{array}{c}-0.5 \\
{[-6.730]} \\
{[.000]}\end{array}$ & N. A. & $\begin{array}{c}1973-2010 \\
\text { ARDL }(1,0,6) \\
\text { rulc } \rightarrow \text { rxr }\end{array}$ & $\begin{array}{c}9.35 \\
2.95[(10)]^{*} \\
4.17[(1)]^{*}\end{array}$ & $\begin{array}{c}-0.207 \\
1988-2010\end{array}$ \\
\hline $\begin{array}{c}\text { El } \\
\text { Salvador }\end{array}$ & N. A. & N. A. & $\begin{array}{c}1.063 \\
{[32.529]} \\
{[.000]}\end{array}$ & N. A. & $\begin{array}{c}-0.0773 \\
{[-3.436]} \\
{[.001]}\end{array}$ & D86 & $\begin{array}{c}1961-2010 \\
\text { ARDL }(1,1,1) \\
\text { rulc } \rightarrow \text { rxr }\end{array}$ & $\begin{array}{c}13.546 \\
\\
2.87[(10)]^{*} \\
4.03[(1)]^{*}\end{array}$ & $\begin{array}{c}-0.292 \\
1994-2010\end{array}$ \\
\hline Finland & N. A. & N. A. & $\begin{array}{c}1.003 \\
{[242.510]} \\
{[.000]}\end{array}$ & $\begin{array}{c}-0.027 \\
{[-2.297]} \\
{[.031]}\end{array}$ & $\begin{array}{c}-0.474 \\
{[-2.773]} \\
{[.010]}\end{array}$ & N. A. & $\begin{array}{c}1971-2010 \\
\text { ARDL }(5,3,6) \\
\text { Both }\end{array}$ & $\begin{array}{c}4.38 \\
2.94\left[[(0)]^{*}\right. \\
4.12[(1)]^{*}\end{array}$ & $\begin{array}{c}-0.549 \\
1960-2010\end{array}$ \\
\hline France & N. A. & $\begin{array}{c}-0.009 \\
{[-8.414]} \\
{[.000]}\end{array}$ & $\begin{array}{c}1.097 \\
{[127.963]} \\
{[.000]}\end{array}$ & $\begin{array}{c}0.027 \\
{[2.066]} \\
{[.050]}\end{array}$ & $\begin{array}{c}-0.533 \\
{[-3.451]} \\
{[.002]}\end{array}$ & N. A. & $\begin{array}{c}1971-2010 \\
\text { ARDL }(2,6,6) \\
\text { Both }\end{array}$ & $\begin{array}{c}4.879 \\
3.41[1(0)]^{\star \star} \\
4.44[1(1)]^{\star \star}\end{array}$ & $\begin{array}{c}-0.201 \\
1960-2010\end{array}$ \\
\hline Germany & N. A. & N. A. & $\begin{array}{c}1.021 \\
{[239.79]} \\
{[.000]}\end{array}$ & $\begin{array}{c}0.016 \\
{[1.886]} \\
{[0.071]}\end{array}$ & $\begin{array}{c}-0.51 \\
{[-4,69]} \\
{[.000]}\end{array}$ & $\begin{array}{l}\text { D86 } \\
\text { D00 }\end{array}$ & $\begin{array}{c}1970-2010 \\
\text { ARDL }(6,6,0) \\
\text { rulc } \rightarrow \text { rxr }\end{array}$ & $\begin{array}{c}6.23 \\
2.953[l(0)]^{*} \\
4.091[1(1)]^{*}\end{array}$ & $\begin{array}{c}0.294 \\
1960-2010\end{array}$ \\
\hline Italy & $\begin{array}{c}1.105 \\
{[1.917]} \\
{[.069]}\end{array}$ & N. A. & $\begin{array}{c}0.758 \\
{[5.994]} \\
{[.000]}\end{array}$ & $\begin{array}{c}0.018 \\
{[2.167]} \\
{[.042]}\end{array}$ & $\begin{array}{c}-0.867 \\
{[-4.401]} \\
{[.000]}\end{array}$ & N. A. & $\begin{array}{c}1981-2010 \\
\text { ARDL }(5,0,1) \\
\text { rulc } \rightarrow \text { rxr }\end{array}$ & $\begin{array}{c}5.496 \\
4.27[l(0)]^{\star} \\
5.44[(1)]^{\star}\end{array}$ & $\begin{array}{c}-0.127 \\
1960-2010\end{array}$ \\
\hline
\end{tabular}

It is worth mentioning that we always found a cointegrating relation between the log of the real effective exchange rate and the log of the real adjusted unit labor cost ratio, and in most cases, also with the real interest rate differential, that is, only in one case for the estimated period, the real interest rate differential did not cointegrate with the other two variables in our ECM framework (this was the case of Sweden), which suggests that this variable was not relevant to explain the changes in the log of the real effective exchange rate. In seven other cases, although the real interest rate differential held a cointegrating long-run 
relationship with the other two variables, its sign was negative (this was the case of Australia, Canada, Denmark, Finland, Japan, Norway, and Spain). This result is a very wellknown puzzle in international finance, which means that positive changes in real interest rate differentials tend to depreciate the real exchange rate. Multiple investigations, in the tradition of covered and uncovered interest parity have also encountered this counterintuitive result for several countries and periods (Engel 2013). However, for the nine remaining countries, the sign of the real interest rate differential was the expected one, suggesting that positive interest rate differentials tend to appreciate the real exchange rate (see table 1).

Table 1 (Cont'd): Econometric Results

\begin{tabular}{|c|c|c|c|c|c|c|c|c|c|}
\hline & $\begin{array}{l}\text { Intercept } \\
\text { (t-Ratio) } \\
\text { [p-value] }\end{array}$ & $\begin{array}{c}\text { Time Trend } \\
\text { Coefficient } \\
\text { (t-Ratio) } \\
\text { [p-value] }\end{array}$ & $\begin{array}{l}\text { LRULCR } \\
\text { Coefficient } \\
\text { (t-Ratio) } \\
\text { [p-value] } \\
\end{array}$ & $\begin{array}{c}\text { Real.Int.Rate.Diff } \\
\text { Coefficient } \\
\text { (t-Ratio) } \\
\text { [p-value] } \\
\end{array}$ & $\begin{array}{c}\text { ECM } \\
\text { Coefficient } \\
\text { (t-Ratio) } \\
\text { [p-value] } \\
\end{array}$ & Dummies & $\begin{array}{c}\text { Regression Date } \\
\& \text { ARDL Order } \\
\begin{array}{c}\text { rulc } \rightarrow \text { rxr or } r x r ~ \\
\text { rulc }\end{array} \\
\end{array}$ & \begin{tabular}{|c|} 
F Statistic \\
Lower And \\
Upper Bounds \\
\end{tabular} & $\begin{array}{l}\text { Correlations } \\
\text { TB \& RULCR }\end{array}$ \\
\hline Japan & N. A. & N. A. & $\begin{array}{c}1.012 \\
{[301.387]} \\
{[.000]}\end{array}$ & $\begin{array}{c}-0.067 \\
{[-4.362]} \\
{[.000]}\end{array}$ & $\begin{array}{c}-0.835 \\
{[-4.705]} \\
{[.000]}\end{array}$ & N. A. & $\begin{array}{c}1977-2010 \\
\text { ARDL }(3,3,2) \\
\text { rulc } \rightarrow \text { rxr }\end{array}$ & $\begin{array}{c}.47 \\
3.01[1(0)]^{*} \\
4.23[1(1)]^{*}\end{array}$ & $\begin{array}{c}0.731 \\
1977-2010\end{array}$ \\
\hline Korea & $\begin{array}{c}3.691 \\
{[7.623]} \\
{[.000]}\end{array}$ & $\begin{array}{c}-0.008 \\
{[-3.634]} \\
{[.001]}\end{array}$ & $\begin{array}{c}0.266 \\
{[2.210]} \\
{[.034]}\end{array}$ & $\begin{array}{l}0.0107 \\
{[2.108]} \\
{[.042]}\end{array}$ & $\begin{array}{c}-0.629 \\
{[-4.497]} \\
{[.000]}\end{array}$ & N. A. & $\begin{array}{c}1965-2010 \\
\text { ARDL }(1,4,1) \\
\text { rulc } \rightarrow \text { rxr }\end{array}$ & $\begin{array}{c}7.36 \\
5.29[\mathrm{II}(0)]^{*} \\
6.35[\mathrm{I}(1)]^{*}\end{array}$ & $\begin{array}{c}-0.465 \\
1960-2010\end{array}$ \\
\hline Mexico & $\begin{array}{c}3.902 \\
{[14.706]} \\
{[.000]}\end{array}$ & N. A. & $\begin{array}{c}0.179 \\
{[3.397]} \\
{[.002]}\end{array}$ & $\begin{array}{c}0.0031 \\
{[1.893]} \\
{[.070]}\end{array}$ & $\begin{array}{c}-0.676 \\
{[-5.904]} \\
{[.000]}\end{array}$ & $\begin{array}{l}\text { D86 } \\
\text { D95 }\end{array}$ & $\begin{array}{c}\text { 1982-2011 } \\
\text { ARDL }(1,0,0) \\
\text { rulc } \rightarrow \text { rxr }\end{array}$ & $\begin{array}{c}7.32 \\
4.24[\mathrm{l}(0)]^{*} \\
5.42[\mathrm{l}(1)]^{*}\end{array}$ & $\begin{array}{c}-0.312 \\
1982-2011\end{array}$ \\
\hline $\begin{array}{c}\text { Netherlan } \\
\text { ds }\end{array}$ & N. A. & $\begin{array}{c}0.009 \\
{[5.896]} \\
{[0.001]}\end{array}$ & $\begin{array}{c}0.918 \\
{[63.585]} \\
{[.000]}\end{array}$ & $\begin{array}{l}0.0381 \\
{[2.745]} \\
{[0.033]}\end{array}$ & $\begin{array}{c}-0.964 \\
{[-4.402]} \\
{[.002]}\end{array}$ & N. A. & $\begin{array}{c}\text { 1990-2010 } \\
\text { ARDL }(4,4,4) \\
\text { Both }\end{array}$ & $\begin{array}{c}6.78 \\
4.59[1(0)]^{*} \\
5.92[l(1)]^{*}\end{array}$ & $\begin{array}{c}-0.814 \\
1971-2010\end{array}$ \\
\hline Norway & N. A. & $\begin{array}{l}0.008 \\
{[2.42]} \\
{[0.021]}\end{array}$ & $\begin{array}{c}0.955 \\
{[35.75]} \\
{[.000]}\end{array}$ & $\begin{array}{l}-0.094 \\
{[-2.53]} \\
{[.016]}\end{array}$ & $\begin{array}{c}-0.152 \\
{[-2.51]} \\
{[.017]}\end{array}$ & N. A. & $\begin{array}{c}\text { 1968-2010 } \\
\text { ARDL }(1,3,4) \\
\text { Both }\end{array}$ & $\begin{array}{c}5.11 \\
3.38[I(0)]^{\star *} \\
4.41[1(1)]^{\star *}\end{array}$ & $\begin{array}{c}0.91 \\
1960-2010\end{array}$ \\
\hline Spain & N. A. & N. A. & $\begin{array}{c}1.01 \\
{[164.1]} \\
{[.000]}\end{array}$ & $\begin{array}{c}-0.0711 \\
{[-2.13]} \\
{[0.048]}\end{array}$ & $\begin{array}{l}-0.32 \\
{[-3.22]} \\
{[.005]}\end{array}$ & N. A. & $\begin{array}{c}1982-2010 \\
\text { ARDL }(4,3,4) \\
\text { rulc } \rightarrow \text { rxr }\end{array}$ & $\begin{array}{c}7.33 \\
3.04[I(0)]^{*} \\
4.26[1(1)]^{*}\end{array}$ & $\begin{array}{c}-0.086 \\
1984-2010\end{array}$ \\
\hline Sweden & N. A. & N. A. & $\begin{array}{c}0.992 \\
{[117.1]} \\
{[.000]}\end{array}$ & N. A. & $\begin{array}{c}-0.187 \\
{[-2.445]} \\
{[.019]}\end{array}$ & N. A. & $\begin{array}{l}1963-2010 \\
\text { ARDL }(3,2) \\
\text { rulc } \rightarrow \text { rxr }\end{array}$ & $\begin{array}{c}3.6 \\
2.47[I(0)]^{\star *} \\
3.36[I(1)]^{\star *}\end{array}$ & $\begin{array}{c}-0.807 \\
1960-2010\end{array}$ \\
\hline Taiwan & N. A. & N. A. & $\begin{array}{c}0.986 \\
{[160.3]} \\
{[.000]}\end{array}$ & N. A. & $\begin{array}{l}-0.363 \\
{[-5.76]} \\
{[.000]}\end{array}$ & N. A. & $\begin{array}{c}\text { 1986-2009 } \\
\text { ARDL }(2,2) \\
\text { Both }\end{array}$ & $\begin{array}{c}21.017 \\
3.56[\mathrm{I}(0)]^{*} \\
4.62[\mathrm{I}(1)]^{*}\end{array}$ & $\begin{array}{c}-0.503 \\
1986-2010\end{array}$ \\
\hline UK & N. A. & N. A. & $\begin{array}{c}0.972 \\
{[200.2]} \\
{[.000]}\end{array}$ & $\begin{array}{l}0.043 \\
{[5.47]} \\
{[.000]}\end{array}$ & $\begin{array}{l}-0.409 \\
{[-6.3]} \\
{[.000]}\end{array}$ & D97 & $\begin{array}{c}1975-2010 \\
\text { ARDL }(1,0,1,1) \\
\text { rulc } \rightarrow \text { rxr }\end{array}$ & $\begin{array}{c}9.77 \\
2.68[I(0)]^{*} \\
4.06[I(1)]^{*}\end{array}$ & $\begin{array}{c}-0.21 \\
1960-2010\end{array}$ \\
\hline us & N. A. & N. A. & $\begin{array}{c}0.972 \\
{[210.9]} \\
{[.000]}\end{array}$ & $\begin{array}{l}0.0271 \\
{[2.42]} \\
{[.019]}\end{array}$ & $\begin{array}{l}-0.411 \\
{[-4.6]} \\
{[.000]}\end{array}$ & N. A. & $\begin{array}{c}\text { 1963-2010 } \\
\text { ARDL }(2,0,0) \\
\text { Both }\end{array}$ & $\begin{array}{c}4.959 \\
2.85[1(0)]^{*} \\
4.05[1(1)]^{*}\end{array}$ & $\begin{array}{c}0.881 \\
1960-2010\end{array}$ \\
\hline
\end{tabular}


It is quite likely that changes in the real exchange rate could lead to corresponding variations of the adjusted real unit labor cost ratio and the real interest rate differential, for example by altering the growth rate of all domestic prices. We therefore made the log of the adjusted real unit labor cost ratio and the real interest rate differential the dependent variables in two ECM for each country. When we took the log of the adjusted real unit labor cost ratio as the dependent variable, we found that in the cases of Argentina, Canada, Finland, France, Netherlands, Norway, Taiwan, and the US, the F-statistic and the ECC were statistically significant, which means that for these eight countries there are multiple feedbacks between the adjusted real unit labor cost ratio and the real effective exchange rate. In the case of the other twelve countries, the direction of the causality goes from the adjusted real unit labor cost ratio to the real effective exchange rate (see table 1). When we took the real interest rate differential as the dependent variables, in none of the cases were both the F statistic and the ECC statistically significant.

Finally, for those countries where we found a positive correlation between the Trade Balance (TB) and the RULCR, we decided, using the ARDL-ECM framework, to do a full model for the log of the Trade Balance (LTB) in order to estimate the long-run relationship between the TB and the RULCR, so we took as independent variables the log of the RULCR, the log of the real GDP, and the log of the World real GDP. The results on table 2 show that for the cases of Germany, Japan, and the US, there is an equilibrium negative long-run relationship (elasticity) between the log of the Trade Balance and the log of the RULCR, which suggests that a relative reduction of the real unit labor cost tends to improve the international competitiveness of these nations. 
Table 2: Econometric Results, Trade Balance Model

\begin{tabular}{|c|c|c|c|c|c|c|c|c|c|}
\hline & $\begin{array}{c}\text { Intercept } \\
\text { (t-Ratio) } \\
\text { [p-value] }\end{array}$ & $\begin{array}{c}\text { Time Trend } \\
\text { Coefficient } \\
\text { (t-Ratio) } \\
\text { [p-value] }\end{array}$ & $\begin{array}{l}\text { LRULCR } \\
\text { Coefficient } \\
\text { (t-Ratio) } \\
\text { [p-value] }\end{array}$ & $\begin{array}{c}\text { LGDP } \\
\text { Coefficient } \\
\text { (t-Ratio) } \\
\text { [p-value] }\end{array}$ & $\begin{array}{c}\text { LWGDP } \\
\text { Coefficient } \\
\text { (t-Ratio) } \\
\text { [p-value] }\end{array}$ & $\begin{array}{c}\text { ECM } \\
\text { Coefficient } \\
\text { (t-Ratio) } \\
\text { [p-value] }\end{array}$ & Dummies & $\begin{array}{l}\text { Regression Date } \\
\text { \& ARDL Order }\end{array}$ & $\begin{array}{c}\text { F Statistic } \\
\text { Lower And } \\
\text { Upper Bounds }\end{array}$ \\
\hline Germany & N.A. & N. A. & $\begin{array}{l}-0.452 \\
{[-2.05]} \\
{[.055]}\end{array}$ & $\begin{array}{l}-0.405 \\
{[-2.18]} \\
{[0.043]}\end{array}$ & $\begin{array}{c}0.4606 \\
{[2.85]} \\
{[0.011]}\end{array}$ & $\begin{array}{c}-0.65000 \\
{[-3.86]} \\
{[0.001]}\end{array}$ & N. A. & $\begin{array}{c}1982-2010 \\
\text { ARDL }(2,3,1,3)\end{array}$ & $\begin{array}{c}5.46 \\
2.78[(10)]^{*} \\
4.10\left[[(1)]^{*}\right. \\
\end{array}$ \\
\hline Japan & N.A. & N.A. & $\begin{array}{c}-1.989 \\
{[-2.831]} \\
{[.009]}\end{array}$ & $\begin{array}{l}0.604 \\
{[2.89]} \\
{[.008]}\end{array}$ & N. A. & $\begin{array}{l}-0.478 \\
{[-4.00]} \\
{[.000]}\end{array}$ & N.A. & $\begin{array}{c}1976-2010 \\
\text { ARDL }(2,6,0)\end{array}$ & $\begin{array}{c}5.12 \\
2.99[(10)]^{*} \\
4.23[(1)]^{*} \\
\end{array}$ \\
\hline Norway & N. A. & N. A. & $\begin{array}{l}3.107 \\
{[2.09]} \\
{[.044]}\end{array}$ & $\begin{array}{c}-1.05 \\
{[-1.95]} \\
{[.058]}\end{array}$ & N. A. & $\begin{array}{c}-0.257 \\
{[-3.59]} \\
{[.001]}\end{array}$ & N. A. & $\begin{array}{c}1968-2010 \\
\text { ARDL }(1,3,3)\end{array}$ & $\begin{array}{c}5.04 \\
2.90\left[(1(0)]^{*}\right. \\
4.08[(1)]^{*} \\
\end{array}$ \\
\hline US & $\begin{array}{l}19.78 \\
{[2.98]} \\
{[0.024]}\end{array}$ & N.A. & $\begin{array}{l}-1.019 \\
{[-2.02]} \\
{[.051]}\end{array}$ & $\begin{array}{l}-0.963 \\
{[-3.57]} \\
{[.001]}\end{array}$ & N. A. & $\begin{array}{l}-0.353 \\
{[-3.79]} \\
{[.001]}\end{array}$ & D73 & $\begin{array}{c}1964-2010 \\
\text { ARDL }(4,0,4)\end{array}$ & $\begin{array}{c}5.98 \\
4.09[(10)]^{*} \\
5.19[1(1)]^{*}\end{array}$ \\
\hline
\end{tabular}

For the case of Norway, the long-run relationship (elasticity) between the log of the TB and the $\log$ of the RULCR turned out to be positive, which suggests that for this country, a relative increase of the real unit labor cost does not have a negative impact on its trade balance (perhaps this is a result of the composition of Norway's main exports: oil and technology associated to the extraction of oil). For the four countries, the $\log$ of their real GDP turned out to be statistically significant and negative; only for the case of Japan the latter relationship turned out to be positive. Finally, only for the case of Germany the log of the World real GDP turned out to be significant and positive, which suggests that to an important degree Germany's trade balance depends on the world real GDP performance.

\section{Concluding Remarks}

An important conclusion of our alternative approach is that neither flexible nor quasiflexible exchange rate regimes will be able to correct structural trade imbalances induced by international competition. That is, trade surpluses and trade deficits are direct consequences of the relative competitive positions of nations. So exchange rate devaluations will only 
have a temporary effect on national competitiveness if the general conditions of production are not improved.

Drawing on Marx, Harrod, and Keynes, we presented theoretical reasons for why trade imbalances ultimately have an impact on the internal liquidity of the economies and thus on the internal interest rate rather than on relative prices. Therefore, if the level of the national interest rate is high enough to create an attractive interest rate differential (e.g., due to a high trade deficit), eventually this positive interest rate differential could trigger an important capital inflow into one nation which could create an exchange rate misalignment, and as a consequence, a persistent trade imbalance and external indebtedness.

Our econometric results using the ARDL-ECM framework confirmed the main hypothesis of this paper, namely that there is an equilibrium long-run relationship between the real effective exchange rate and the adjusted real unit labor cost ratio for 16 OECD countries, Taiwan, and 3 developing countries. However, when we investigated the possibility of a long-run relationship among the real effective exchange rate, the adjusted real unit labor cost ratio and the short-run real interest rate differential, we could only find a meaningful cointegrating vector with correct signs for the cases of Belgium, France, Germany, Italy, Korea, Mexico, Netherlands, UK, and the US, which indicates that for these countries a positive real interest rate differential tends to appreciate their real exchange rates.

Our correlation and cointegration analysis suggests that for all the countries under analysis but Norway, there is a negative relationship between the Trade Balance and the RULCR, which hints that a relative reduction of the real adjusted unit labor cost tends to improve the international competitiveness of these nations. 
In short, the generalized modernization of technology to raise productivity and to lower unit labor costs, is the only long-term solution to the problem of competitive disadvantage. More precisely, cost reductions can only be produced by the introduction of more efficient technologies, or, in the short-term, by the reduction of the real wage rate. Therefore, as long as the least competitive economies at the international level do not improve their general technical conditions of production, these countries national industries will be structurally uncompetitive and as a result, these countries could have permanent trade deficits.

\section{References}

Antonopoulos, R. (1997), "An Alternative Theory of Real Exchange Rate Determination for the Greek Economy. New York: Unpublished PhD dissertation, New School for Social Research.

Botwinick, M. (1988), Regularities in price changes as an effect of change in distribution. Cambridge Journal of Economics.

Foley, D. (1986). Understanding Capital: Marx's Economic Theory. Cambridge MA, Harvard University Press.

Enders, Walters (1995), Applied Econometric Times Series. John\& Sons, Inc.

Feliz y Sorokin (2008), Rigidez estructural del tipo de cambio? El caso de Argentina a la luz de un enfoque marxista. Interpretaciones heterodoxas de las crisis económicas en Argentina y sus efectos sociales. Compiladores: Fernando Toledo y Julio Neffa. Eds. Trabajo \& Sociedad y Conicet.

Ge, Qi (1993), An Alternative Theory of the Terms of Trade. New York: Unpublished PhD dissertation, New School for Social Research.

Guerrero, Diego (1995), Competitividad teoria y practica. Editorial Ariel.

Harrod, Roy (1957), International Economics. Chicago: The University of Chicago Press.

Harvey, John. Exchange Rates and Trade Flows: A Post Keynesian Analysis, 2013. Online document, accessed May 11: http://www.economicsnetwork.ac.uk/heterodox/lecturenotes

- (2005) Post Keynesian versus Neoclassical Explanations of Exchange Rate Movements: A Short Look at the Long Run, Texas Christian University, Working Paper Nr. 05-01. 
Hill, R. Carter, Griffiths, Willian E., and Lim, Guay (2011), Principles of Econometrics. 4th edition. John Wiley \& Sons.

Hunt, E. K. and Lautzenheiser (2011), M. History of Economic Thought: A Critical Perspective. M.E Sharpe, Inc.

Martinez-Hernandez, Francisco (2010), An Alternative Theory of Real Exchange Rate Determination: Theory and Empirical Evidence for the Mexican Economy, 1970-2004. Investigacion Economica.

Marx, Karl (1981), Capital: A Critical of Political Economy. London: Penguin Books.

- (1973), Grundrisse: Outlines of the Critique of Political Economy. Penguin, online version by Andrew Lannan: http://www.marxists.org/archive/marx/works/1857/grundrisse/index.html

Milberg, W. (1994), Is Absolute Advantage Passe? Toward a Kenynesian /Marxian Theory of International Trade. Great Britian: In., Glick, Mark.

Milberg, W. (2002), Say's Law in the Open Economy: Keynes's Rejection of the Theory of Comparative Advantage. In Keynes, Uncertainty, amd the Global Economy. Eds: Dow and Hillard, Massachusetts: Edward Elgar Publishing Limite.

Pasinetti, L. (1971), Lectures on the Theory of Production. New York: Columbia University Press.

Pesaran Bahram and Hashem Pesaran (2009), Time Series Econometrics using Microfit 5.0: A User's Manual . Oxford University Press.

Ricardo, David (2004), On the Principles of Political Economy and Taxation. Indiana: Liberty Fund. Editied Vol.I.

Ruiz-Napoles, Pablo (2010), Costos unitario laborales verticalmente integrados por rama en Mexico y Estados Unidos 1970-2000. Investigacion Economica.

- (1996), Alternative Theories of Real Exchange Rate Determination, A Case Study: The Mexican Peso and the US Dollar. New York: Unpublished PhD dissertation, New School for School of Research.

Salgado, Melissa, Gochez, Roberto, Bolanos, Francisco (2010), Los determinates estructurales de la evolucion de los flujos comerciales entre El Salvador (ES) Y la Union Europea (UE). Friendrich Ebert Stiftung.

Sarich, John (2006), What Do We Know About The Real Exchange Rate? A Classical Cost of Production Story. Review of Political Economy.

Shaikh and Antonopoulos (2013), Explaining long term exhange reate behavior in the United States and Japan. Alternative Theories of Competition: Challenges to the Orthodoxy. Eds: Moudud, Bina, and Mason, Routledge.

- (1998), Explaining long term exhange reate behavior in the United States and Japan. The Jerome Levy Economics Institute.

Shaikh, Anwar (2012), Competition Matters: China's Exchange Rate and Balance of Trade. The Forum, Summer. 
— (1999a), Explaining the U.S. trade deficit. Washington D.C.: Testimony before the Trade Deficit Review Commission.

- (1999b), Real exachange rates and international mobility of capital. The Jerome Levy Economics Insititute.

- (1991), Competition and Exchange Rates: Theory and emprirical Evidence. New York: New School for Social Reserach.

— (1980), On the laws of international exchange. Cambridge: Cambridge University Press.

Smith, Adam (1999), The Wealth of Nations Books I-III. England: Penguin Books.

\section{Appendix}

This appendix describes the methodology to construct real effective exchange rates, relative real adjusted unit labor costs, and real interest rate differentials for two set of countries, all these series were calculated in annual index form $(\mathbf{2 0 0 2}=\mathbf{1 0 0})$ for the period 1960-2010. The first set of 16 countries includes: Australia, Belgium, Canada, Denmark, Finland, France, Germany, Italy, Japan, South Korea, Netherlands, Norway, Spain, Sweden, UK, and the US. The second set of 4 countries includes: Argentina, El Salvador, Mexico, and Taiwan. We focus first on the methodology for the first set of countries and then describe the methodology for the second set of countries.

Our real effective exchange rates $(r x r)$ is a trade-weighted real effective exchange rate index which has as its main components for each country the manufacturing price index (pmfg, national currency), the index of the nominal exchange rate $(e=$ Foreign Currency/Dollar) and a geometric traded weighted average of manufacturing prices $((\boldsymbol{p} \boldsymbol{m g} * \boldsymbol{e}) \boldsymbol{o e c d})$. The first both indexes were obtained from the U.S. Bureau of Labor Statistics.

$$
\text { (1) } r x r_{c, t}=\frac{p m f g_{i, t} * e_{i, t} * 100}{((p m g * e) o e c d)_{t}}
$$

Where $i$ stands for country (e.g., Australia,.., U.S.), $t$ stands for time (e.g., 1960,.., 2010) and where $p m f g_{i, t} * e_{i, t}=p m f g_{i, t} * \frac{e_{i, t}}{100}$.

The denominator of formula 1 , which is a manufacturing price index for the 16 OECD countries, is a geometric traded weighted average which uses total flows of trade $(w=\mathrm{X}+\mathrm{M}$ in millions of US Dollars). Each year $(t)$ takes into account just 16 countries ( $i$ ). The trade flows data were obtained from the IMF (IFS). The methodology for the estimation of the denominator is described in the following three formulas:

$$
(p m f * e))_{\text {oecd }}=\prod_{i=1}^{16} x_{i, t}
$$




$$
x_{c, t}=\operatorname{pmfg}_{i, t} * e_{i, t}^{(\text {Trade Weights })_{i, t}} \quad \text { where } \quad \text { Trade Weights } s_{i, t}=w_{i, t} / \sum_{j=1}^{16} w_{j, t}
$$

Trade weights reflect country's share in the total trade flows $(M+X)$ of the 16 OECD countries. The real adjusted unit labor cost ratio (rulcadjratio) was calculated on the basis of formula 2 below. The manufacturing unit labor cost indexes from all the countries were obtained from the U.S. Bureau of Labor Statistics (national currency basis). The indexes to calculate the adjustment component, $C P I$ and PPI, were obtained from the U.S. Bureau of Labor Statistics and OECD, respectively. PPI stands for manufacturing producer price index. Although CPI stands for consumer price index, we calculated this index as a ratio of unit labor cost and the real unit labor cost, both in local currency.

$$
\text { (2) } \text { rulcadjratio }_{i, t}=\frac{R U L C a d j_{i, t} * 100}{R U L C a d j O E C D_{t}}
$$

Where $R U L C a d j i, t=\left(R U L C_{i, t} *\left(\frac{C P I_{i, t}}{P P I_{i, t}}\right)\right)$ and the real unit labor cost is $R U L C_{i, t}=\left(\frac{U L C_{i, t}}{C P I_{i, t}}\right) * 100$

The denominator in (2), which is a manufacturing price index for the 16 OECD countries, is a geometric traded weighted average that was calculated as a compound geometric traded weighted average as follows:

$\operatorname{RULCadjOECD}_{t}=\left(\right.$ RULCoecd $\left._{t} *\left(\frac{\text { CPIoecd }_{t}}{\text { PPIoecd }_{t}}\right)\right)$

The geometric traded weighted average for the real unit labor for each year $(t)$ was obtained as follows:

$R U L$ Coecd $_{t}=\prod_{i=1}^{16} y_{i, t}$ where $y_{i, t}=R U L C_{i, t}^{(\text {Trade Weight })_{i, t}}$

The geometric traded weighted average for the CPI for each year $(t)$ was obtained as follows:

CPIoecd $_{t}=\prod_{i=1}^{16} z_{c, t} \quad$ where $z_{i, t}=C P I_{i, t}^{(\text {Trade Weight })_{i, t}}$

The geometric traded weighted average for the PPI for each year $(t)$ was obtained as follows:

PPIoecd $_{t}=\prod_{i=1}^{16} x y_{i, t} \quad$ where $\left.\quad x y_{i, t}=P P I_{i, t}^{(\text {Trade } W e i g h t ~}\right)_{i, t}$ 
The data to calculate real interest rate differentials was obtained from the International Monetary Fund (IMF, IFS). We mainly used Treasury bill rates with a maturity of 3 months. In order to calculate the real interest rate differential for each country, we first calculated the nominal interest rate differentials for each country under the basis of the following formula:

\section{(3) intratediff $_{t}=$ IntRates $_{t}-$ IntRateOecd $_{t}$}

Where intratediff stands for nominal interest rate differential, IntRates stands for nominal interest rate, and IntRateOecd stands for a geometric traded-weighted average which was calculated on the basis of the following two equations:

IntRateOecd $_{t}=\prod_{i=1}^{16} x z_{i, t} \quad$ where $\quad x z_{i, t}=$ IntRates $_{i, t}^{(\text {Trade Weight })_{i, t}}$

Thus, the real interest rate differential for each country was calculated as a difference between intratediff and the growth rate of a geometric traded-weighted average of the producer price index from the 16 OECD countries (gppiratio):

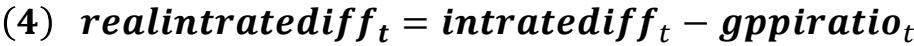

Where gppiratio $_{t}=\left(100 * \frac{\left(\left(p p i / \text { ppiOECD }_{t}-(\text { ppi } / \text { ppiOECD })_{t-1}\right)\right.}{(\text { ppi/ppiOECD })_{t-1}}\right)$

and ppi $/$ ppiOECD $t_{t}=\left(P P I_{t} *\left(\frac{100}{\text { ppiOECD }}\right)\right)$. The geometric traded-weighted average of the

producer price index was calculated on the basis of the following two calculations:

$\operatorname{ppiOECD}_{t}=\prod_{i=1}^{16} y z_{i, t}$ and $y z_{i, t}=P P I_{i, t}^{(\text {Trade Weight })_{i, t}}$. 